\title{
Penggunaan Jeruk Nipis sebagai Salah Satu Upaya Konservasi Secara Tradisional pada Prasasti Sukawana D
}

\author{
Coleta Palupi Titasari, Zuraidah, dan Ni Ketut Puji Astiti Laksmi \\ Jurusan Arkeologi Universitas Udayana \\ astitilaksmi@yahoo.com
}

\begin{abstract}
Abstrak : Konservasi adalah tindakan untuk mencegah dan menghambat proses kerusakan atau pelapukan, tindakan menangani kerusakan, serta menjaga agar suatu benda tetap berada pada kondisi yang baik sesuai dengan aslinya. Bertolak dari pengertian tersebut, masyarakat Desa Sukawana, Kecamatan Kintamani, Kabupaten Bangli, Bali merupakan salah satu masyarakat desa yang melakukan konservasi tradisional terhadap peninggalan arkeologi berupa prasasti Sukawana D yang telah diwarisi secara turun temurun. Usaha yang dilakukan adalah perawatan dengan menggunakan jeruk nipis secara rutin. Penggunaan jeruk nipis sebagai bahan perawatan prasasti Sukawana D terbukti sangat bermanfaat menghindari proses korosi. Perawatan ini dimaksudkan untuk memperlambat kerusakan prasasti. Upaya sederhana dan tradisional yang dilakukan oleh masyarakat Desa Sukawana memperoleh hasil nyata berupa lestarinya prasasti Sukawana D.
\end{abstract}

Kata kunci: Perawatan, Jeruk Nipis, Prasasti

\begin{abstract}
Abstrak : Conservation is the act to prevent and inhibit damage or weathering processes, action dealing damage, and to keep an object remains in good condition in accordance with the original. Sukawana villagers, district of Kintamani, Bangli Regency, Bali is one of the rural communities that traditional conservation of the archaeological heritage in the form of inscriptions Sukawana D. Which has been inherited from generation to generation. The treatment using lime on a regular basis. The use of lime as a material inscription Sukawana D treatment proved to be very helpful to avoid corrosion process. This treatment is intended to slow the damage to the inscription. Simple and traditional efforts undertaken by villagers Sukawana, obtaining tangible results in the form of inscriptions for sustainability Sukawana D.
\end{abstract}

Keywords: Care, Lime, Inscription

\section{A. Latar Belakang}

Masyarakat Bali pada umumnya mempunyai kesadaran yang tinggi tentang masa lampaunya. Hal ini terbukti dengan adanya kepercayaan yang kuat terhadap cikal bakal keluarga. Demikian juga dengan hasil budaya yang diciptakan, kemudian diwariskan kepada generasi berikutnya akan menjadi kebanggaan dan simbol, bahkan merupakan identitas budaya. Berbagai jenis tinggalan budaya yang kemudian disebut tinggalan arkeologi baik yang bergerak maupun tidak bergerak mengandung nilai dan mempunyai makna tinggi dalam kehidupan masyarakat Bali (Tara Wiguna, 2005: 16).

Kenyataan menunjukkan bahwa sebagian tinggalan arkeologi yang ditemukan di Bali masih berfungsi seperti sedia kala (living monument), terutama benda-benda yang diciptakan sebagai media pemujaan. Ada kalanya benda-benda yang dahulu diciptakan untuk memenuhi kebutuhan jasmani yang bersifat teknis, dalam perkembangan selanjutnya berubah fungsi menjadi benda religius, baik sebagai media pemujaan maupun untuk kepentingan religius lainnya. Selain nilai religius tersebut, benda cagar budaya juga mempunyai nilai seperti nilai estetika, nilai simbolis/asosiatif, nilai informatif dan nilai ekonomis (Drajat, 1995 : 4-6).

Prasasti adalah salah satu tinggalan arkeologi yang masih banyak ditemukan di Bali. Menurut Bekker (1972:4) prasasti diidentifikasikan sebagai dokumen resmi, yang ditulis di atas batu dan logam, dirumuskan menurut kaidah-kaidah tertentu, berisikan anugerah dan hak yang dikaruniakan dengan beberapa upacara. Dari bukti-bukti tertulis berupa prasasti ini juga dapat diketahui berbagai peristiwa yang telah terjadi pada masa yang lalu 
(Soekanto, 1988: 8).

Meskipun masyarakat Balipada umumnya sangat patuh pada pesan leluhur dan/atau takut terkutuk oleh śapatha yang terdapat dalam prasasti, akan tetapi yang memprihatinkan adalah mereka terkadang tidak mengerti isi keseluruhan prasasti yang dikeramatkan tersebut. Hal ini karena prasasti dibuat ratusan tahun lalu dengan memakai bahasa yang sukar dipahami. Di samping itu, penulis prasasti tidak bermaksud untuk mewariskan keterangan-keterangan yang lengkap kepada generasi yang akan datang termasuk kepada generasi yang masih hidup pada masa kini. Dengan demikian, penulis prasasti tidak memandang perlu untuk memberikan keterangan yang sejelas-jelasnya, karena bagi mereka yang hidup sezaman dengannya sudah jelas maksud yang terkandung dalam prasasti tersebut (Boechari, 1977:13).

Munculnya fenomena masyarakat untuk menelusuri kembali asal-usul atau leluhur mereka melalui tinggalan prasasti yang telah mereka warisi secara turun temurun merupakan suatu gejala yang menarik untuk diteliti. Di samping itu, pluralisme yang muncul dalam era global justru menimbulkan tuntutan agar setiap orang atau pihak boleh memaknai warisan budaya menurut gagasannya. Perlu disadari bahwa ada kalanya pengetahuan masyarakat masih minim terhadap prosedur, sistem, dan teknik pemeliharaan benda cagar budaya untuk pelestariannya. Oleh karena itu, pelaksanaan pemeliharaan terkadang menyimpang dari ketentuanketentuan teknik yang berlaku. Hal ini karena benda cagar budaya tersebut dianggap sebagai 'milik' mereka, maka pemeliharaan dan perawatannya dilakukan berdasarkan kemufakatan masyarakat bersangkutan, dengan tidak memperhatikan nilai-nilai budaya, nilai arkeologis, dan sejarah yang terkandung dalam benda tersebut. Akibatnya data arkeologis dan sejarah masa lampau menjadi rusak. Kondisi semacam ini menjadi ancaman dalam upaya pelestarian benda cagar budaya. Selain sebagai ancaman, kondisi seperti ini menjadi kendala dan tantangan bagi instansi terkait, pemerhati masalah-masalah budaya, dan pihak-pihak yang berkepentingan terhadap keberadaan benda cagar budaya (Tara Wiguna, 2005:7).

Di satu sisi hambatan tersebut menyebabkan beberapa bagian dari warisan budaya seperti prasasti itu sendiri terkadang belum pernah tersentuh. Padahal dari segi kuantitas maupun kualitas bangsa Indonesia, khususnya Bali kaya akan tinggalan prasasti. Di sisi lain, pada hakikatnya semua benda cagar budaya akan mengalami interaksi dengan lingkungannya. Interaksi tersebut sebenarnya merupakan bagian dari proses alam yang tidak dapat dihindari. Semua benda di alam ini akan mengalami proses penuaan alamiah dan akan mengalami proses degradasi yang mengakibatkan menurunnya kualitas bahan benda cagar budaya. Apabila proses penuaan tersebut terpacu oleh faktor penyebab pelapukan, maka proses hancurnya komponen bahan yang digunakan akan lebih cepat.

Konflik kepentingan dan pluralisme yang berkembang dalam masyarakat juga menimbulkan wacana baru dalam visi pelestarian. Selama ini, harus diakui kebijakan pelestarian selalu diarahkan pada upaya 'tidak mengubah' atau 'mengembalikan kekeadaannya semula' suatu warisan budaya. Kebijakan seperti itu dirasakan terlalu kaku, cenderung sempit, dan kurang dapat mewadahi upaya pemanfaatannya. Seolah-olah pelestarian hanyalah untuk benda yang dilestarikan itu sendiri. Kebijakan seperti itu sekarang sering dipermasalahkan dan di berbagai tempat sudah mulai ditinggalkan. Memang disadari sepenuhnya bahwa warisan budaya adalah sumberdaya budaya yang tak terbaharui (nonrenewable), terbatas (finite), dan khas (contextual). Karena itu, segala upaya untuk mempertahankan nilainya harus selalu diusahakan. Namun, disadari pula bahwa upaya mempertahankan nilainya itu tidak selalu berarti 'sekedar mengabadikan keadaan semula' tanpa mempertimbangkan berarti atau tidaknya upaya pelestarian itu bagi masyarakat.

Sebaliknya, pelestarian justru harus dilihat sebagai suatu upaya untuk mengaktualkan kembali warisan budaya dalam konteks sistem yang ada sekarang. Tentu saja, pelestarian harus dapat mengakomodasi kemungkinan perubahan, karena pelestarian harus diartikan sebagai upaya untuk memberikan makna baru bagi warisan budaya itu sendiri (Tanudirjo, 1996: 6).

Kesadaran akan pentingnya pelestarian warisan budaya pada masa kini sesungguhnya sudah semakin 
meningkat. Bahkan, banyak di antara pencinta dan pemerhati warisan budaya yang berkeyakinan bahwa warisan budaya itu tidak hanya merupakan warisan, tetapi merupakan pusaka bagi bangsa Indonesia. Artinya, warisan budaya itu mempunyai kekuatan yang dapat dimanfaatkan untuk membantu dan melindungi bangsa ini dalam menapaki jalan di masa depan. Sebagai pusaka, warisan budaya itu harus tetap dijaga agar kekuatannya tidak hilang dan dapat diwariskan kepada generasi penerus tanpa berkurang nilainya (Tanudirjo, 2003:1).

Selain itu, setiap masyarakat pada hakikatnya selalu mempunyai konsep-konsep pelestariannya sendiri (etnoconservation). Upaya pelestarian yang mereka lakukan secara mandiri terbukti cukup efektif dan sangat membantu pemerintah. Karena itu, peran serta masyarakat amat perlu diberikan tempat dalam arah kebijakan pengelolaan yang baru. Sejauh mana langkah-langkah yang dilakukan oleh masyarakat Bali dalam upaya melestarikan prasasti yang telah diwarisi secara turun temurun tercermin dalam upaya yang dilakukan oleh masyarakat Desa Sukawana, Kecamatan Kintamani, Kabupaten Bangli?

\section{B. Pembahasan}

\section{Prasasti Sukawana D}

Desa Sukawana merupakan salah satu desa kuno yang banyak menyimpan tinggalan-tinggalan arkeologi berupa prasasti, disamping tinggalan berupa arca. Salah satu prasasti yang tersimpan di desa tersebut adalah Prasasti Sukawana D. Prasasti ini disimpan di Pura Bale Agung, Desa Sukawana yang merupakan Pura Kabyangan masyarakat Desa Sukawana, tepatnya di Pelinggih Meru Tumpang Lima (suatu bangunan suci beratap tumpang lima). Bangunan ini juga dikenal dengan nama Gedong Penyimpenan yang biasanya difungsikan sebagai tempat penyimpanan benda-benda yang disakralkan atau disucikan seperti prasasti, arca, dan pratima (suatu arca, perwujudan dari dewa yang disembah, biasanya terbuat dari kayu atau emas dengan ukuran relatif kecil).

Prasasti Sukawana D terdiri dari tujuh lempeng tembaga, di setiap lempeng terdapat 47- 60 kata. Tipe aksara yang digunakan dalam prasasti Sukawana D yaitu tipe aksara Bali Kuno dengan bentuk sempurna, agak persegi, dipahat halus, agak miring, rapi, dan indah. Adapun bahasa yang digunakan secara dominan yaitu Bahasa Jawa Kuno walaupun ada beberapa istilah yang menggunakan Bahasa Bali Kuno.

Penamaan prasasti Sukawana D karena prasasti ini ditujukan dan ditemukan di Desa Sukawana dengan urutan kelompok prasasti D. Berdasarkan riwayat penemuannya, prasasti tersebut ditemukan setelah prasasti Sukawana AI, Sukawana AII, Sukawana B, dan Sukawana C. Di dalam prasasti tertulis banwa sikawana (lempeng IIIb baris ke-4) yang menunjukkan bahwa prasasti tersebut merupakan prasasti yang ditujukan untuk Desa Sukawana dan dikeluarkan pada tahun 1222 Saka ketika masa pemerintahan Raja Patih Kebo Parud.

Alasan dikeluarkannya prasasti Sukawana D yaitu untuk menjaga ketenteraman masyarakat di Desa Sikawana (Sukawana). Isi prasasti tersebut sebagian besar menjelaskan tentang kewajiban yang harus dipenuhi oleh masyarakat, serta terdapat pula hak-hak istimewa yang diberikan oleh raja yaitu berupa aturan perdagangan yang berlangsung di Desa Sukawana.

\section{Kondisi Prasasti Sukawana D}

Pada umumnya prasasti dibuat dari bahan-bahan yang tahan lama. Walaupun demikian, tidak sedikit prasasti yang mengalami kerusakan karena telah berumur cukup lama sehingga terjadi penurunan kadar material yang digunakan. Sebagai salah satu warisan budaya, prasasti sangat dijaga keberadaannya oleh masyarakat penerusnya. Dengan demikian masyarakat berperan penting dalam upaya pelestarian tinggalan masa lampau khususnya tinggalan prasasti, seperti prasastiprasasti yang terdapat di Desa Sukawana.

Prasasti Sukawana D sudah pernah diteliti oleh $\mathrm{R}$ Goris yang kemudian dipublikasikan oleh Machi Suhadi dalam karyanya yang berjudul Himpunan Prasasti Bali. Kemudian pada tanggal 30 Oktober 2012 prasasti tersebut kembali diteliti oleh tim epigrafi Balai Arkeologi Denpasar yang juga diikuti oleh seorang mahasiswa arkeologi Universitas Udayana. Pada penelitian ini dilakukan pembacaan ulang secara langsung terhadap prasasti tersebut dan diikuti dengan transkripsi ke dalam huruf latin. Selanjutnya 
transliterasi ke dalam bahasa Indonesia dilakukan di kantor Balar Denpasar.

Sampai saat ini prasasti-prasasti tersebut masih terjaga dengan baik, walaupun umurnya sudah tujuh abad. Bentuk dan kondisi ketujuh lempeng prasasti Sukawana D bisa dikatakan tidak berubah secara signifikan dari awal pembuatannya. Secara umum benda-benda yang terbuat dari bahan logam termasuk prasasti akan mengalami kerusakan yang disebabkan oleh beberapa faktor berikut.

a. Korosi

Korosi merupakan gejala destruktif yang mempengaruhi hampir semua logam. Faktor yang berpengaruh dan mempercepat korosi di antaranya adalah air dan kelembaban udara, elektrolit berupa asam atau garam, adanya oksigen, permukaan logam yang tidak rata, serta logam dalam potensial reduksi (Sutopo, 2012:29). Tanda-tanda terjadinya korosi pada ketujuh lempeng prasasti Sukawana D hampir tidak ditemukan meskipun telah diketahui bahwa permukaan prasasti tidak rata karena adanya pahatan-pahatan aksara. $\mathrm{Hal}$ ini kemungkinan disebabkan karena prasasti ini tersimpan di dalam sebuah kotak yang terbuat dari kayu (keropak) yang terlebih dahulu dilapisi kain kasa, sehingga kemungkinan prasasti ini terkena air hujan (asam) relatif kecil. Pada masyarakat Bali penggunaan kain kasa baik yang berwarna kuning, putih, ataupun hitam memiliki nilai sakral. Demikian juga halnya dengan air laut (garam) kemungkinannya sangat kecil karena daerah Sukawana sendiri berada di pegunungan tepatnya di lereng Gunung Batur.

\section{b. Jamur}

Jamur termasuk jenis mikroorganisme yang sering dijumpai pada benda-benda logam termasuk prasasti. Kotoran berupa jamur juga ditemukan pada ketujuh lempengan prasasti Sukawana D yang ditandai dengan adanya warna kehijau-hijauan. Munculnya jamur karena prasasti tersebut sangat jarang dikeluarkan dari keropak bahkan dari gedong penyimpenan. Prasasti Sukawana D hanya dikeluarkan jika ada upacara keagamaan (Dewa Yadnya atau piodalan) di Pura Bale Agung Desa Sukawana yang waktunya telah ditentukan setahun sekali.

\section{c. Kotoran lain}

Jenis kotoran lain misalnya debu sisa-sisa pembakaran dupa dan bunga sisa upacara bisa dikatakan tidak bersentuhan langsung dengan prasasti karena hanya ditemukan di luar tempat penyimpanan (keropak).

\section{Perawatan yang Dilakukan terhadap Prasasti Sukawana D \\ Perawatan yang dilakukan oleh masyarakat} Desa Sukawana secara rutin menjadi salah satu hal positif untuk menjaga keutuhan prasasti. Setiap upacara piodalan di Pura Bale Agung Desa Sukawana dilakukan prosesi pembersihan prasasti. Proses ini diawali dengan menghaturkan upakara (sesajen) kemudian dilanjutkan dengan membuka gedong penyimpenan dan menurunkan prasasti yang hanya boleh dilakukan oleh seorang pemangku. Kemudian prasasti dibawa ke suatu bangunan tempat proses pembersihan akan dilakukan. Selanjutnya prasasti Sukawana D dikeluarkan dari keropaknya, demikian juga dengan kain kasa putih dan kuning yang dipakai sebagai pembungkus prasasti dibuka.

Bahan yang dipergunakan untuk membersihkan prasasti hanyalah jeruk nipis. Jeruk nipis tersebut digosok-gosokkan pada permukaan prasasti sampai bersih kemudian diseka dengan kain kasa. Pembersihan hanya boleh dilakukan oleh Jero Mangku Alit yang berjumlah delapan orang. Mereka adalah anakanak/remaja yang sudah ditentukan akan menjadi generasi penerus yang berwenang melakukan tradisi pembersihan prasasti dan setelah dewasa akan menjadi seorang pemangku. Setelah dilakukan pembersihan kemudian dilanjutkan dengan pembacaan prasasti tersebut. Menjelang dimasukkan kembali ke dalam keropak dilakukan kembali pengelapan dan pembungkusan prasasti dengan menggunakan kain kasa agar bekas-bekas keringat tidak menempel pada lempengan prasasti.

Pengetahuan masyarakat Sukawana tentang 
pemanfaatan jeruk nipis sebagai bahan perawatan prasasti sejak zaman lampau karena adanya kearifan lokal. Hal ini karena daerah Sukawana Kec. Kintamani merupakan daerah penghasil jeruk bahkan sangat terkenal dengan jeruk Kintamani. Jeruk nipis (Citrus Aurantifolia) merupakan jeruk asam yang banyak dan umum dipakai oleh masyarakat. Buah jeruk nipis dapat digunakan untuk membersihkan karat, karena mengandung asam sitrat (Sutopo, 2012:40).

\section{Kesimpulan dan Saran}

Upaya sederhana dan tradisional yang dilakukan oleh masyarakat Desa Sukawana, Kecamatan Kintamani, Kabupaten Bangli, Bali merupakan tindakan yang dilakukan secara turun temurun dan rutin dilaksanakan, sehingga diperoleh hasil nyata

\section{Daftar Pustaka}

Bekker, S.J.WM. 1972. Ilmu Prasasti Indonesia (Seri Risalah Pengantar Pengajaran dan Pembelajaran Sejarah). Yogyakarta : Jurusan Sejarah IKIP Sanata Dharma.

Boechari, M. 1977 "Epigrafi dan Sejarah Indonesia". Majalah Arkeologi Th I No. 2. Jakarta : Fakultas Sastra Univ. Indonesia Hal. 1-20.

Drajat, H. Untoro. 1995. "Manajemen Sumberdaya Budaya", dalam Buletin Cagar Budaya: Pelestarian Benda Cagar Budaya dan Upaya Pencerdasan Bangsa (1) 1 : 3. Jakarta : Direktorat Perlindungan dan Pembinaan Peninggalan Sejarah dan Purbakala.

Soekanto, Soerjono. 1988. Sosiologi: Suatu Pengantar. Jakarta: Raja Grafindo Persada. berupa lestarinya prasasti Sukawana D. Penggunaan jeruk nipis sebagai bahan perawatan prasasti Sukawana D terbukti sangat bermanfaat menghindari proses korosi.

Penelitian tentang metode-metode konservasi tradisional sangat perlu dilakukan sebagai upaya menambah pemahaman tentang budaya masa lalu. Namun sebaliknya, memberikan pemahaman ilmiah kepada masyarakat tentang hal-hal yang sesungguhnya sudah dilakukan secara turun-temurun sangatlah penting agar masyarakat lebih memahami dan melakukannya secara benar serta tidak beralih ke metode-metode yang belum teruji hasilnya secara nyata.

Tanudirjo, D.A. 1996. "CRM Sebagai Manajemen Konflik”. Artefak No. 19 Februari 1996. Jakarta

.2003. "Gagasan Untuk Nominasi Benda Cagar Budaya di Indonesia”. Makalah disusun dalam rangka Lokakarya Penyusunan Piagam Pelestarian Pusaka Untuk Indonesia di Kaliurang, 30 September - 3 Oktober 2003.

Tara Wiguna, I G.N. 2005. "Peran Serta Masyarakat Dalam Upaya Pelestarian Benda Cagar Budaya”. Stupika Arkeologi Udayana. Denpasar. 